\title{
The Development of Teaching Materials Drama for Students Class Viii Junior High School (Structural Approach Based Development Research)
}

\author{
Kautsar Tifani ${ }^{1}$, Anjasmara $^{2}$, Hidayat $^{3}$ \\ Kuningan University, Indonesia \\ \{Tifani.kautsar@uniku.ac.id\}
}

\begin{abstract}
This study aims to produce a drama teaching material design for junior high school students. This research is based on a preliminary study which shows that drama teaching materials for junior high school are still very minimal. Even though teaching materials have a strategic position in the curriculum. Teaching materials in this case are not only a means of achieving basic competencies, but also as a medium for developing creativity and sensitivity training in dormitories. In the concept of the National Curriculum (Kurnas), teaching materials are designed by teachers according to student needs. Based on the observations, the teacher still uses the textbook as a complete handbook without adding any other references. As a result, learning Indonesian, especially literature (drama) becomes less attractive. With the additional teaching materials that the writer compiled, it is hoped that students will feel helped and are able to master the competencies outlined in the syllabus and be able to develop themselves. The focus of this research is to produce a drama appreciation teaching material design for Class VIII junior high school students. The research method used is R\&D with an analytic descriptive approach that seeks to logically describe facts in the presence of appropriate or logical evidence. The analytical descriptive approach is used because it is related to the concept of qualitative research. Based on the results of the analysis of the elements of content, artistic, creative process, and performance, the conclusions of this research (teaching material design) are as follows. (1) The cover contains the writing of the title, class, level of education unit, accompanied by pictures; (2) the title "Drama Art for Students (Guide to Understanding Content, Artistic and Performance Guidelines) SMP / MTs"; (3) Table of contents and pages; (4) The material is presented in a simple and communicative manner. The material consists of the understanding of drama and drama script in brief, about understanding the elements of the drama script content, understanding the artistic content of the drama script based on understanding the elements of the content, and the steps for the drama performance and also equipped with a material concept map. (5) Exercises / tests presented in the form of descriptions and performance; (6) there is a bibliography, glossary, index, and author's biography.
\end{abstract}

Keywords: development of teaching materials; drama

\section{Introduction}

Indonesian subjects studied in schools generally aim to make students able to listen, speak, read and write. The basic competencies developed based on these four skills are interrelated and of course support each other in the development of the three main areas, namely learning Indonesian, literature and literacy development. Learning Indonesian for students is expected 
to be able to increase the spirit of nationalism and an understanding of language as a means of knowledge emerges. Not only that, in speech acts or communication, it is hoped that students can become communicative and productive Indonesian speakers.

Meanwhile, literary learning which is always side by side and related to Indonesian language learning is the majority in the form of theories about the repertoire of classical and modern Indonesian literature which generally aim to develop, study the moral or personality, cultural, social and aesthetic values of students. Literary works such as poetry, prose fiction and drama have all of these which of course have their own classification for students and the general public as the realm of learning and study. The carrying capacity of both central and local governments in developing and advancing education in Indonesia actually already exists, such as the provision or addition of books as a means of literacy, appeals or policies regarding the procurement of books related to Indonesian language and literature, training- Indonesian language and literature teacher training, to provide space for third parties to contribute to building education in Indonesia to be more advanced in a different and legal way, such as publishing companion books, worksheets, language and literature modules, and other things which can make it easier for educators or students to carry out the learning process, especially in this case Indonesian Language and Literature.

Improvements in the quality of education, especially for Indonesian language and literature (SMP and SMA), are starting to be felt in big cities that have different literacy facilities. However, this is not the case in the regions, as time goes by, these barriers or obstacles continue to emerge. As it is felt in Kuningan Regency, West Java province. The author sees from various sides, especially the carrying capacity of the literacy process itself. Both language and literature are still lacking. This was also stated by the association of Indonesian language teachers in SMP in Kuningan regency, for example. One of them is responding to the lack of comfortable literacy places both at school and outside as if, the lack of places for providing books, the lack of companion books (modules and others) that are specific or indepth on the materials that will be delivered to students at school. Especially the lack of books, modules or teaching materials to complement as well as help and simplify Indonesian literary materials, be it poetry, prose fiction and drama.

Educators have difficulty developing their abilities because of a lack of literacy for themselves and for their students, so that another obstacle arises, namely the lack of creative human resources. Libraries in schools or regional libraries have not been able to meet the needs, especially the needs of literary materials. Many consider that it is still not balanced. Not only that, the number of bookstores in the Kuningan district as one of the supporting capacities for increasing literacy is not as many as expected, and the existing books are more focused on general science, while Indonesian literature is still minimal.

Another way is to look elsewhere, such as to the city of Cirebon, Jakarta or Bandung, this is very time consuming and labor intensive, so the number of obstacles is increasing and complex. Ideally, all the needs of educators and students, especially in terms of "literary literacy" are met, but in fact they have not. So with this the writer tries to make and compile a teaching material about drama material as a solution to overcome these problems.

\section{Method}

The research method used is R\&D with an analytic descriptive approach that seeks to logically describe facts in the presence of appropriate or logical evidence. The analytical 
descriptive approach is used because it is related to the concept of qualitative research. Dick, dkk. (2009: 12) state that "Research and Development is a process used to develop and validate education product". The research and development approach was then modified with the Jolly and Bolitho development model. The Jolly and Bolitho development model consists of the following steps. 1) Identification of needs; 2) Needs Exploration; 3) Contextual Realization; 4) Pedagogical Realization; 5) Physical Production; 6) Product Trial; and 7) Evaluation. The seven steps are then applied into 4 stages of development research, namely: introduction, development planning, validation, and implementation.

\section{Result and Discussion}

The data used in this study is a drama script that will be used as material for analysis of content and artistic elements and the creative process of drama staging is a drama script entitled "Raja Gedang Atah" by Aan Sugianto Mas. This was done by the researcher, the manuscript was used as a support for the completeness of drama teaching material data that was compiled and adjusted to the needs of KI - KD on drama material in class VIII SMP / MTs. Analysis of the artistic elements that will be arranged based on the content elements that have been previously analyzed. The content elements that have been analyzed have an important role in artistic preparation, and are considered by the compilers in making decisions in making artistic concepts of drama scripts that have been read in full. Suntini (2014) state that.

To research a literary work, of course, cannot be separated from the structural element. This is reasonable because other literary works of reality or fiction are in language packaging. So to conduct this research, researchers must move away from the structure. The stages of analyzing the artistic elements of the performance of the drama script entitled Raja Gedang Atah by Aan Sugianto Mas are based on the analysis of the elements of the script. Some of the things that the researchers analyzed for the artistic part were as follows: 1 . The concept of the stage / setting 2. The concept of movement / blocking 3. The concept of makeup / makeup 4. Dressing up. In responding to what was conveyed by Haryamawan and the understanding from KBBI about creativity and the process of creativity, it turns out that to grow one's creativity requires encouragement, both in the form of what is seen (read), heard and what is felt. After this is obtained, students must be given space and time to more freely develop ideas and ideas freely.

The process of creativity of students can be found after they have read and understood the teaching materials that the author compiled (about understanding the elements of content, artistic and drama performance steps). The following is the result of the creative process of staging drama after reading and understanding the teaching materials that the author compiled in the drama learning process in class VIII SMPN 2 Cilimus and SMP ITUS Jalaksana, Kuningan regency - West Java. Researchers documented some of the results of the students' creative processes in several research locations. The first research location is in class VIII, SMPN 2 Cilimus - Kuningan Regency. In the research process (taking documentation), previous researchers had collaborated with the school to carry out research on the creative process of drama staging. The research was conducted for five days from 24 (Wednesday), 25 (Thursday), 26 (Friday), 29 (Monday) and 30 (Tuesday) January 2018. With the details of the research as follows: 3 days of students reading and understanding books text, 1-day analyzing content and artistic elements, and 1day students carrying out drama performances in class. 
After the five-day research process, there are several interesting things that can be used as a conclusion, namely the existence of positive results, especially the proof of a creative process that arises from students during the process or preparation of drama presentation.

After students are able to analyze the elements of content, students are also able to conceptualize an artistic performance such as, making the concept of a stage layout (attached), movement (attached), make-up / makeup, (attached), fashion / costume (attached) and all. carried out based on the understanding of the content element analysis carried out by the performance group that has been formed. Not only up to artistic conceptualization, students are to able try to present a drama from a script that has been analyzed for content and artistic elements. Even though it is not staged in its entirety (only a few scenes) it indicates or proves a creative process that emerges from these students. The creative process can be seen when students are able to determine and arrange property in the classroom without the help of their teacher, students are able to determine stage areas for the movement of actors independently (without the help of the teacher), students are able to determine the concept of clothing to be used by the actor independently, and students are able to determine facial features even though it is only simple and applied in the presentation of the Drama performance in front of the class.

The teaching materials that will be developed in this research are textbooks. Tech books are books that are prepared for the learning process and contain learning materials or materials that will be studied by students. The textbooks compiled in this study are Dramatic Arts for Students (Guide to Understanding Content, Artistic and Performance Steps). This textbook was developed based on the analysis of content, artistic and creative processes in drama performances. The textbooks designed in this study are based on material about drama in class VIII SMP contained in the 2013 curriculum. The textbooks are expected to create and develop the knowledge and skills of students in appreciating the art of drama either through writing a drama script or in the process of staging a drama.

This is also in line with the characteristics of the 2013 curriculum in the learning process, namely developing a balance between knowledge and skills. For this reason, so that the knowledge and skills possessed by students can be comprehensively formed, the learning process that they teach must be continuous or not separated between KI 3 and KI 4. Thus, drama learning developed in the teaching materials that the authors compiled is integrated with learning to examine the characteristics of linguistic elements and rules in drama texts in the form of scripts or performances and presenting drama in the form of a stage or script. To master all of that, students must have the ability to analyze the content elements to understand the contents of the drama script, and must also be able to understand the artistic elements to carry out the drama staging process based on the elemental analysis of the content of the drama script that has been done previously.

Table 1. Design of Teaching Material

\begin{tabular}{lll}
\hline No. & \multicolumn{1}{c}{ Component } & \multicolumn{1}{c}{ Characteristic } \\
\hline & Introduction & There is writing the title, class, level of education unit. \\
Cover & Title & $\begin{array}{l}\text { Accompanied by pictures } \\
\text { "Seni Drama Untuk Siswa" (Panduan Memahami Isi, Artistik } \\
\text { dan Panduan Pementasan) SMP/MTs } \\
\text { Contains the contents of the textbook along with the pages }\end{array}$ \\
& Table of Content & Consists of the main material (KI and KD) \\
& Learning Activity & The material is presented in a simple and communicative \\
manner. The material consists of the understanding of drama
\end{tabular}


and drama script in brief, about understanding the elements of the drama script content, understanding the artistic content of the drama script based on understanding the elements of the content, and the steps for the drama performance. And also equipped with a material concept map.

Test Latihan / tes disajikan dengan bentuk uraian dan unjuk kerja

Closing

Reference

Contains books that are used as a source of writing

3

Glossaries

Contains a list of important words or terms

Index

Contains a list of words or important terms found in the book and arranged alphabetically which provides information on the page where the word or term was found.

Author Biography Contains a glimpse of the author's identity

\section{Conclusion}

Based on the results of the analysis of the elements of content, artistic, creative process, and performance, the conclusions of this research (teaching material design) are as follows. (1) The cover contains the writing of the title, class, level of education unit, accompanied by pictures; (2) the title "Drama Art for Students (Guide to Understanding Content, Artistic and Performance Guidelines) SMP / MTs"; (3) Table of contents and pages; (4) The material is presented in a simple and communicative manner. The material consists of the understanding of drama and drama script in brief, about understanding the elements of the drama script content, understanding the artistic content of the drama script based on understanding the elements of the content, and the steps for the drama performance and also equipped with a material concept map. (5) Exercises / tests presented in the form of descriptions and performance; (6) there is a bibliography, glossary, index, and author's biography.

\section{References}

[1] Creswell, John. W. (2012). Educational Research. New York: Upper Sadle River, NJ: Pearson.

[2] D. Jolly, D. \& Bolitho, R. (2011). A Framework for Materials Writing. In: Tomlinson, B. (ed). Materials Development in Language Teaching. (2nd ed). Cambridge: Cambridge University Press.

[3] Emzir \& Rohman, Saifur (2015) Teori dan Pengajaran Sastra. JAKARTA: PT Raja Grafindo Persada

[4] Heryadi, Dedi (2010) Metode Penelitian Pendidikan Bahasa. Bandung: PUSBILL.

[5] Muchlis, Masnur dan A. Hayati (------) Latihan Apresiasi Sastra. Triana Media.

[6] Prastowo, Andi (2015) Panduan Kreatif Bahan Ajar Inovatif. Yogjakarta: DIVA Press.

[7] Ratna, Nyoman Kutha (2010) Teori, Metode dan Teknik Penelitian Sastra. Yogyakarta: Pustaka Pelajar.

[8] Ratna, Nyoman Kutha (2010) Teori, Metode dan Teknik Penelitian Sastra. Yogyakarta: Pustaka Pelajar.

[9] Santosa, Eko, dkk. (2008) Seni Teater Jilid I. Jakarta: Departemen Pendidikan Nasional.

[10] Sugiantomas, Aan (2010) Langkah Awal Menuju Apresiasi Sastra. Kuningan: Program Studi Pendidikan Bahasa dan Sastra Indonesia. 
[11] Suntini, Sun. (2014). Nilai Moral Dalam Naskah Drama "Sobrat" Karya Arthur S. Nalan (Sebuah Kajian Perspektif Akhlak Islam Ditinjau Dari Tema, Karakter Tokoh, Konflik, Dan Amanat). Fon : Jurnal Pendidikan Bahasa dan Sastra Indonesia 